\title{
Evaluation of Digital Marketing Use in the Promotion of Latgale Region Tourism
}

\author{
Ligita Karvele \\ Faculty of Economics and Management \\ Rezekne Academy of Technologies \\ Rezekne, Latvia \\ ligita.karvele@gmail.com
}

\begin{abstract}
Destination communication is essential for improving the economic and social development of cities, regions and countries, as tourism has become a major component of gross domestic product in most countries of the world. The development of information technology has fundamentally changed the use of traditional communication tools. Due to the development of modern information technologies, the Internet has become an integral part of tourism communication. Aim of the research is to explore the use of digital marketing in tourism promotion in Latgale region. Research methods-document analysis, statistical data analysis, survey - surveyed tourism information providers in Latgale region; statistical grouping, reading method, interview. The results of the research show that only $20 \%$ of Latgale region tourism information providers are actively involved in the use of social media. In the work of tourism information providers more attention is paid to printed materials than to video materials in the digital environment. But the most effective means of digital marketing is that all tourism information providers emphasize the importance of social networks. Digital Marketing Costs has only $40 \%$ of the Latgale region tourism information providers and they make between 100 and 3000 euros per year. On Visitlatgale.com and latgale.travel, most of the analyzed digital marketing criteria are not present. Latgale marketing action plan is quite varied and wide where costs are for many exhibitions both in Latvia and abroad, visits of Latvian tour operators and journalists, visits of foreign tour operators and bloggers, training seminars, but the marketing plan for 2019 does not include expenses for digital marketing. Latgale Region Tourism Association Ezerzeme marketing plan necessary to provide expenditure for the development of a communication plan - actively should be used funded projects possibilities, for example costs can be partly covered by the European Union's European Agricultural Fund for Rural Development (EAFRD) and the Rural Development Program. Latgale Region Tourism Association needs to attract project funding for tourism information providers training in digital marketing. More attention should be paid to publishing video materials and attracting appropriate specialists. Latgale Planning Region and Rezekne Municipality should improve tourism websites Latgale.travel and visitlatgale.com.
\end{abstract}

Keywords—digital marketing, Latgale region, social networks, tourism promotion.

\author{
Daina Znotiņa \\ Faculty of Economics and Management \\ Rezekne Academy of Technologies \\ Rezekne, Latvia \\ Daina.Znotina@rta.lv
}

\section{INTRODUCTION}

The Internet provides an opportunity for potential tourists themselves to search for information, to choose where and when to look for information, and not to wait for when the information from the tourist service provider will be sent. An appropriate online presence, an attractive website and effective social media management make the city, the region or the country visible, and forms the basis for attracting tourists. Understanding how online communication in a tourist destination can be improved can affect competitiveness and thus the economy of the area. Currently, websites, social networks and mobile applications are the most common platforms for promoting tourist destinations.

Latvian Tourism Development Guidelines 2014-2020 shows that one of the main directions of action is to ensure the visibility of Latvian tourism offer in the target markets, especially by using modern means of communication. The guidelines emphasize that the development of tourism is influenced by use of technologies. It facilitates access to information on tourist destinations, attractions and services, and reduces the cost of marketing activities in the long term. Accessibility of the Internet is a key factor, therefore it is emphasized that at the same time, the collection and availability of information on tourist destinations needs to be more and more coordinated, and tourism organizations and information centers play an important role here [1], [2].

Situation analysis shows that Latgale has problems with communication because there is no unified development goal and strategy for a region with a common platform and responsible, necessary is a professional approach to planning and marketing, highlighting unique advantages, creating experience and communicating. The Latgale Region Tourism Association Ezerzeme has to work with researchers, educational institutions because it is important to study how the information providers of Latgale region promote the offer on digital channels, because successful operation in the digital environment promotes competitiveness, promotes quality and productivity improvement, introduction of innovations [3]. 
Object of the research: tourism resources in Latgale region. Subject of the research: digital marketing.

Aim of the research: to explore the use of digital marketing in tourism promotion in Latgale region.

Tasks of the research: To get to know and analyze literature on digital marketing, its tools and their use in tourism; Explore how tourism resources of Latgale region are promoted in Internet sources - what digital marketing tools are used, evaluate the use of digital marketing of tourism in Latgale region in the work of tourism information providers, as well as to do the expert survey in order to obtain professional opinion regarding the research problem; Draw conclusions and make proposals for a more successful use of digital marketing in Latgale region tourism promotion.

Hypothesis of the research: Digital marketing is used poorly to promote the tourism resources of the Latgale region.

\section{Materials AND Methods}

Research methods:

- Document analysis - planning documents that regulate tourism activity- Latvian tourism marketing strategy and other national tourism policy documents, analyzed tourism marketing plan of Latgale region, finances;

- Statistical data analysis - website activity statistics, Latgale tourism statistics;

- Survey - surveyed tourism information providers in Latgale region;

- Interview - conducted with a tourism specialist to get a professional understanding of the problem being studied.

\section{RESULTS AND DisCUSSION}

The tourist destination is defined as "country, region, city or other place that attracts tourists"[4]. The World Tourism Organization defines tourism as a place people want to visit [5]. The definition of tourist sites also shows the interaction between the supply and demand of a tourist site, the product and the customer as the main marketing elements, as one of the most important features of the tourism site is highlighted - a set of products consisting of separate products. Many product creators are involved in creating a product for a tourist destination but the product itself is a combination of products and services [6].

Tourism marketing is defined as a management concept based on the specificity of a tourism site, based on market competition and public interest, and is characterized by a number of stakeholders. Territorial marketing is defined as a spatial planning process that involves meeting the needs of a targeted market [7]. Determining the needs, wishes and interests of the target market is essential, as well as ensuring that the customer satisfaction level is more effective than competitors do [8].

Promotion is defined as the most convincing way to deliver the message in the right direction at the lowest possible cost [9].

In different sources of information, digital marketing is called different:
- Internet (Web 2.0.) Marketing and online advertising, also called e-marketing, Web marketing, online marketing, is the promotion of products and services on the Internet.

- Internet marketing is the use of the Internet and other digital technologies with traditional methods to achieve marketing goals. Marketing through electronic media such as the web, email, interactive television and wireless multimedia with customer-specific and behavioral digital data [10].

- Internet marketing (also known as e-marketing, Web marketing or digital marketing) is a comprehensive term for marketing products and/or services online - and like many comprehensive terms, internet marketing means different things for different people [11].

- Digital marketing, product or brand advertising using one or more types of electronic media differs from traditional marketing because channels and methods are used that allow the organization to analyze marketing campaigns and understand what works and what isn't usually in real time.

There are different definitions of digital marketing, but the basic principle of the Internet is that users add value to content creation using many online applications including blogs and social networks [10], [12].

A survey of tourism information providers in Latgale region (tourism information centers, tourism information points and tourism organizers) was carried out in order to find out the habits, efficiency and results of use of social networks. Questionnaires were used to identify the use of digital marketing in the work of Latgale tourism information providers. According to the form of the survey - electronic survey on the Internet, distances between researcher and researcher - remote, survey procedures - individual, question forms - with closed questions. Survey with Restrictions - only a specific Latgale region tourist information provider can provide a response. Use of open-ended - unstructured answer questions and closed - structured answers questions questions of dichotomy choice answers and scale-type choice answers questions. The survey used the terms 1 , $2,3,4,5$, which are in ascending order of importance: 1 lowest and 5 highest. The survey held from November 22 to November 27, 2018. It was created on docs.google. com and was sent to all 16 tourism information centers in the Latgale region:

- Aglona tourism information center;

- Baltinava district tourism consultant;

- Balvi tourism information center;

- Cibla district tourism organizer;

- Dagda tourism information center;

- Daugavpils tourism information center;

- Kārsava tourism information point;

- Krāslava tourism information center;

- Līvāni tourism information center;

- Ludza tourism information center;

- Preili and Riebiṇi tourism information center; 
- Rēzekne tourism information center;

- Rēzekne district tourism information center;

- Rugāji tourism information center;

- Vil̦aka tourism information center;

- Zilupes district tourism organizer.

The general set is all providers of tourism information in Latgale region. All responses submitted were taken into account as each response in the study is relevant. In total, 15 responses were received.

The results of the survey show that only $20 \%$ of Latgale region tourism information providers are actively involved in the use of social media.

Most - 14 out of 15 respondents have a Facebook account, with a second place in Twitter, then Instagram, which has 5 tourism information providers, then Draugiem.lv - 4, Instagram - 3, Vimeo and elsewhere 1.

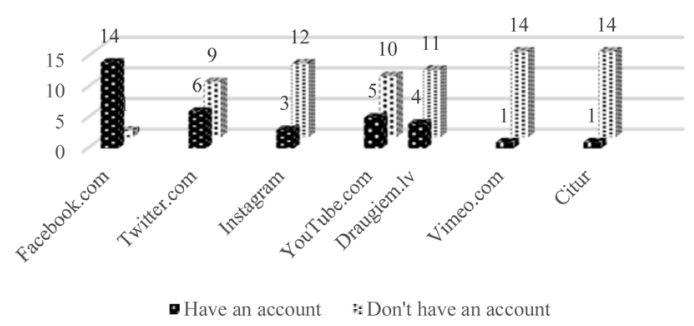

Fig.1. Respondents' answers to the survey question "Do you as a tourist information provider have an account in one of the social media (Facebook, Twitter, Instagram, Youtube, Draugiem, vimeo)?", number of information providers (created by the authors).

$38 \%$ of all tourism information providers use hashtags but $62 \%$ do not use them.

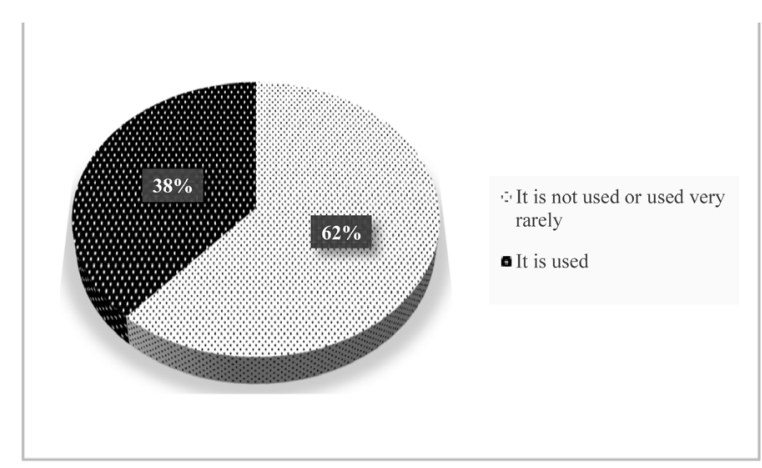

Fig.2. Respondents' answers to the survey question "When publishing information, do you use hashtags?", \% (created by the authors).

Most of Tourist Information Providers - 40\% in the Facebook account publishes the content every day but $27 \%$ a few times a week, the rest less but $7 \%$ have no accounts. $60 \%$ don't have a Twitter account but 13\% publish the content a few times a week. $80 \%$ don't have an Instagram account but $20 \%$ publish the content a few times a week. $67 \%$ do not have a YouTube account but $20 \%$ publish their content about half a year. $73 \%$ have no Draugiem.lv accounts but $13 \%$ publish their content about once a month. 93\% are not Vimeo accounts but 7\% publish their content about once a year. In the work of tourism information providers more attention is paid to printed materials than to video materials in the digital environment.

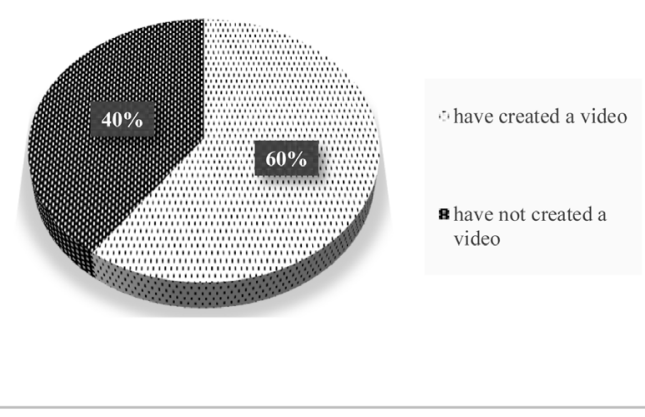

Fig.3. Respondents' answers to the survey question "Over the past 3 years, have tourism video materials about your city/county been created? ", \% (created by the authors).

Target audience for publishing information in social networks is the inhabitants of Latvia. Often they are also local, county, Latgale residents, potential visitors, tourism information providers, tour operators, media, and least foreigners, families with children, niche tourists, and active social network users.

But the most effective means of digital marketing is that all tourism information providers emphasize the importance of social networks.

Digital Marketing Costs has only $40 \%$ of the Latgale region tourism information providers and they make between 100 and 3000 euros per year.

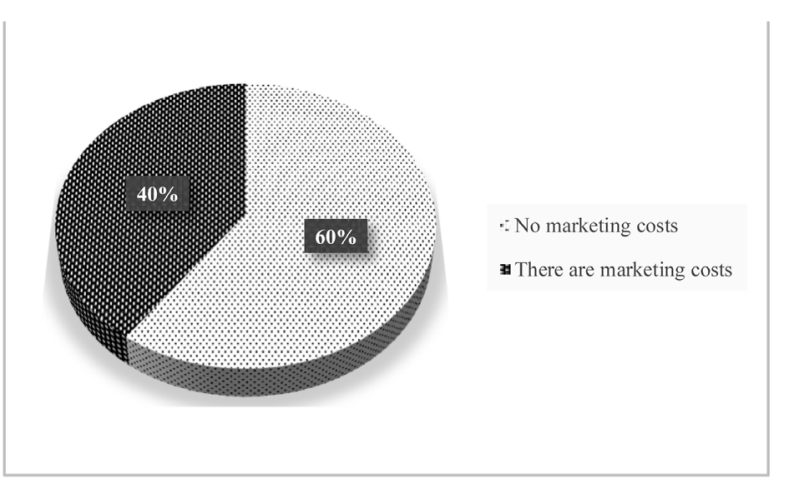

Fig.4. Respondents' answers to the survey question "Do you have digital marketing costs as a tourist information provider? "\% $\%$ (created by the authors).

Most of the respondents do not use paid services because they only use free tools and work voluntarily. $68 \%$ of tourism information providers do not have an account in any social media (Facebook, Twitter, Instagram, Vimeo, Youtube) but 32\% have an account. Most part - 14 out of 15 respondents have a Facebook account, Twitter ranks second, then Instagram.

Using the information available in the literature analysis, several criteria were set for evaluating the website. The official website of Latgale region is visitlatgale.com [13] and is managed by Latgale Region Development Agency. There are 2 websites in Latgale tourism where the second is http://latgale.travel/ [14]. This website was also evaluated. This site has been created because a new and modern website of Latgale tourism is needed. By comparing the analytical data of both websites it can be concluded that the visitaltgale.com 
website is visited by more people, which is $33 \%$ more than latgale.travel. During the previous years Latgale was advertised with this website, also in brochures, at various tourism exhibitions, and was advertised more on the internet at visitlatgale.com. Visitlatgale.com has a more used website, has a higher number of user and page views as the website for tourism is used longer than latgale. travel. On visitlatgale.com and latgale.travel, most of the analyzed digital marketing criteria are not present so there should be improvements to make websites work efficiently and be a convenient tool for potential and existing Latgale region visitors. Google analytics data shows that visitlatgale.com is a more used website, it has a higher number of user and page views what can be explained by the fact that the website in the tourism industry is already in use for a long time - longer than latgale.travel.

Every website has its own pros and cons. To improve digital marketing, the informative arrangement of visitlatgale.com is planned, optimization of the website latgale.travel with pictograms, optimization of Google maps, introduction of Facebook Latgale.travel, and introduction of Instagram to visitlatgale, Twitter Latgale.travel are planned. Self-assessment of tourism information providers in digital marketing shows that only $20 \%$ are actively involved in the use of social media.

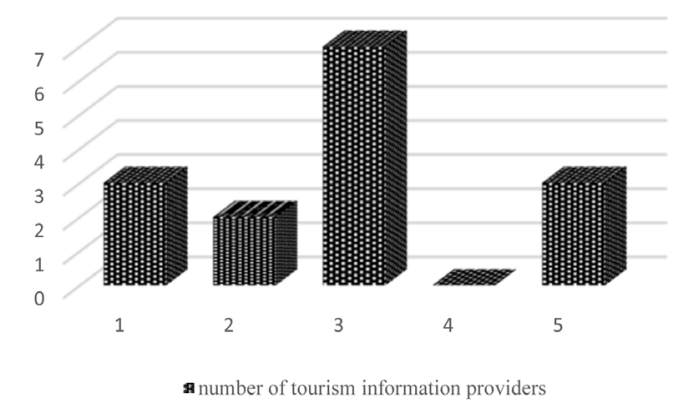

Fig.5. Respondents' answers to the survey question "How do you think how active is your involvement as a tourist information provider in social media usage and digital marketing (1-weak engagement, 5 -very active)? ", the number of information providers (created by the authors).

The research was followed by an interview with Lìga Kondrate - Chairman of the Board of the Latgale Region Tourism Association Ezerzeme (Research Method - Expert Survey). This was done through a onetime tourism specialist interview to gain a professional understanding of the current situation and future plans for digital marketing in the Latgale region. Professional opinion and suggestions for improving the situation were heard. By type of interview - structured, by form individual. Interview held at Ludza Tourism information centre, at 10 a.m., November 29, 2018. Questions were read from the record sheet. During the interview Liga Kondrate emphasizes the important role of Google maps in the digital marketing of tourism, as it allows to find and view objects of interest. Travelers nowadays often visit unscheduled objects and if an object is marked on a Google map, the traveler can easily find it and include it on its route, as well as make a booking immediately. For improvement of this issue should be responsible Latgale region tourism information centers. The Whatsapp application on mobile phones is also important in work for tourism information providers [15].

Exploring the marketing plan of the Latgale Region Tourism Association "Ezerzeme" for 2019 [16] can conclude that the marketing plan is quite diverse and wide where costs are for many exhibitions both in Latvia and abroad, visits of Latvian tour operators and journalists, visits of foreign tour operators and bloggers, training seminars, but the marketing plan for 2019 does not include expenses for digital marketing. Tourism association Ezerzeme in the marketing plan of 2019 foresees expenses of 2800.00 euros for printed materials. About 3000.00 euros is provided for training seminars and the Latgale Tourism Conference, which includes training on topical topics in the work of tourism information providers and entrepreneurs, including topics on digital marketing and its topicalities.

\section{CONCLUSIONS}

It was concluded that the Latgale Region Tourism Association Ezerzeme marketing plan necessary to provide expenditure for the development of a communication plan - actively should be used funded projects possibilities, for example costs can be partly covered by the European Union 's European Agricultural Fund for Rural Development (EAFRD) and the Rural Development Program. The PROSPERO public relations company offers to develop a Latgale communication plan aimed at the European target audience and, for example, Asia, and it would cost around 15,000 euros + VAT, including a company presentation on the established plan, as well as training of tourism information providers in Latgale region. The focus of the plan should be on Latgale's values, vision, events, including more detailed and more readily available information, tools with the ability to book, see what to see, how to communicate effectively through blogger / influenza experience, with a defined strategic approach, the tactics chosen, and to develop a program to market. Estimating Expenses for a Communication Plan will make it possible to implement it successfully and, therefore, the use of digital marketing in Latgale regional tourism will be more effective. Latgale Region Tourism Association needs to attract project funding for tourism information providers training in digital marketing, for example from now on from 04.02.2018. to 04.03.2018 The Rural Support Service has announced the acceptance of project applications in the EAFRD and Rural Development Program measure "Support for the development of rural tourism", where it is possible to receive support for the development and development of rural tourism services, marketing of rural tourism services and marketing campaigns for promotion of rural tourism in rural environment and expansion of new markets. This project could include seminars, conferences and training in digital marketing. Trained tourism information providers will be able to work more effectively in digital marketing, thus attracting more 
visitors to the region. Latgale region tourism information providers must change their approach to marketing focus more on digital marketing, mark all local tourist attractions on Google maps, create tourism packages, routes - events in Latgale must be combined with visits to other objects, as well as be able to present such products digitally - what, where, how to book, apply, etc. digitally, but not calling. Be more active in using social media, such as creating accounts on Instagram, Twitter, Youtube, and Vimeo, as well as providing digital marketing costs for online tools like Facebook.com that helps you get a wider audience of published content. It is recommended to be available in Whatsapp app by providing stakeholders with quick information in the digital environment. For more effective marketing you should use the option to use paid tools (such as on Facebook or Instagram to expand the audience). More active operation in digital marketing and the existence of multiple social network accounts will make it possible to capture a wider range of potential visitors, thereby attracting more visitors to the region. More attention should be paid to publishing video materials and attracting appropriate specialists. Latgale Planning Region has to introduce functions for suggestions and recommendations on the website visitlatgale.com, which allows travelers to share information, write reviews and experiences, ask questions directly, book directly, implement route planning tools, provide a tool for live streaming from various events, expanded reality features, introduce guides, travel agencies, transport and its rental, detailed access possibilities, as well as information about the region's brand profile - identity, flag, coat of arms. Rēzekne Municipality should implement a feature on the Latgale.travel website, where visitors can view and share information on Latgale social networking sites. In order to improve digital marketing it would be necessary to introduce forum, chat, online support, online booking, possibility to view maps and brochures, to be available for information about Latgale, its culture and traditions, identity, brand, easily accessible joint videos of Latgale. The introduction of these functions will improve the use of digital marketing in Latgale tourism, making search for information for potential and existing visitors more convenient and accessible.

Main conclusion is that Latgale tourism information providers use social networks inappropriate. Not everyone has social media accounts, tourism information providers do not use paid tools, as well as lack of knowledge in digital marketing. Latgale Region Tourism Marketing Plan does not foresee expenses for digital marketing, most of the evaluated criteria are not found on the regional websites.

As a result of the study, the hypothesis was confirmed because Latgale tourism information providers use social networks inappropriate. Not everyone has social media accounts, tourism information providers do not use paid tools, as well as lack of knowledge in digital marketing. Latgale Region Tourism Marketing Plan does not foresee expenses for digital marketing, most of the evaluated criteria are not found on the regional websites.

\section{REFERENCES}

[1] V. Dombrovskis, "Guidlines of Latvian Tourism Development 2014-2020," Ministry of Economics, p. 61, 2014. [Online]. Available: www.visitdaugavpils.lv/.../Latvijas-tūrisma-attīstības-pamatnostādnes-2014.-2020.gadam .doc [Accessed September 23, 2018].

[2] LIAA Tourism Department, "How to develop tourism in Latvia?", Latvian tourism marketing strategy 2018.-2023., p.15, 2018. [Online]. Available: https://www.celotajs.lv/cont/prof/ news/2018/Turisma_marketinga_strategija_2018_2023.pdf [Accessed June 11, 2018].

[3] A. Van der Steina, "Problēmas Latgales regiona tūrisma nozarē jeb Kā es braucu baudīit Latgales viesmīlību? Tūrisma un ilgtspējas pētijumu laboratorija", presented on Latgale tourism conference, Rezekne, Latvia, 2015.

[4] LR Ekonomikas ministrija, Tūrisma un viesmīlības terminu skaidrojošā vārdnīca, 2008, pp. 298.

[5] UNWTO, Handbook on Tourism Destination Branding. UN WTO: Spain, 2009, pp. 159.

[6] D. Buhalis, "Marketing the Competitive Destination of the Future", Tourism Management, vol. 21, no. 1, p. 97., 2000. [Online]. Available: https://www.academia.edu/164837/Marketing the competitive destination of the future [Accessed August 20, 2018], https://doi.org/10.1016/S0261-5177(99)00095-3

[7] P. Kotler and J. Makenz, Marketing for Hospitality and Tourism. Second Edition- Upper Saddle River: Prentice Hall, 1999, pp. 650.

[8] V.T.C. Middleton, Marketing in Travel and Tourism (3rd edn) Oxford: Butterworth -Heinemann, 2001, pp. 487. [Online]. Available: https://books.google.lv/books?id=8svzsNJ7fcEC\&printsec $=$ frontcover\&hl $=1 \mathrm{v} \&$ source $=$ gbs ge summary $\mathrm{r} \&$ cad $=0 \# \mathrm{v}=$ onepage \&q\&f=true [Accessed August 21, 2018], https://doi.org/10.1002/jtr.367

[9] C. Maccabe, Marketing communications in tourism \& hospitality: concepts, strategies and cases. Oxford: Elsevier, 2009, pp. 220. [Online]. Available: https://books.google.lv/ books?id=GvYJBAAAQBAJ\&pg $=$ PR3\&lpg $=$ PR $3 \&$ dq $=$ Marketing + communications + in + tourism $+\% 26+$ hospitality: + concepts, + strategies + and + cases + maccabe\&source $=$ bl\&ots $=$ S5tgdtl-Np\&sig=ACfU3U3ziGEq rLJjS1 toOzEGtTL02uJUA\&hl=lv\&sa=X\&ved=2ahUKEwjyjaTbvNbhAhUHtIsKHTwYDwMQ6AEwBXoECAkQAQ\#v=onepage\&q=Marketing\%20 communications $\% 20 \mathrm{in} \% 20$ tourism $\% 20 \% 26 \% 20$ hospitality $\% 3 \mathrm{~A} \% 20$ concepts $\% 2 \mathrm{C} \% 20$ strategies $\% 20$ and $\% 20$ cases $^{2} \% 20$ maccabe\& $\mathrm{f}=$ false [Accessed August 25, 2018].

[10] D. Chaffey, F. Ellis-Chadwick, R. Mayer and K. Johnston, Internet Marketing: Strategy, Implementation and Practice. 4th Edition. Prentice Hall, 2009, pp. 559. [Online]. Available: https:// books.google.lv/books?id=HcoR12EZXiwC\&printsec=frontcover\&hl $=1 \mathrm{v} \&$ source $=$ gbs ge summary $\mathrm{r} \& \mathrm{cad}=0 \# \mathrm{v}=0$ onepage\&q\&f=false [Accessed September 5, 2018].

[11] G. Kaur, The importance of digital marketing in the tourism industry, International Journal of Research - Granthaalayah, vol. 5, no. 6, pp. 72., 2017. [Online]. Available:https://zenodo.org/ record/815854\#.XLC4YqSE6 8Articles [Accessed September 7, 2018], https://doi.org/10.5281/zenodo.815854

[12] S. Parise, P. J. Guinan, Marketing Using Web 2.0. Proceedings of the 41 st Hawaii International Conferece on System Sciences, 2008, pp.1. [Online]. Available: https://www.academia. edu/17431342/Marketing_Using_Web_2.0 [Accessed September 7, 2018],

[13] www.visitlatgale.com [Accessed: Sept. 10, 2018].

[14] http://latgale.travel// [Accessed: Sept. 10, 2018].

[15] Kondrāte, L., the head of Latgale region tourism association Ezerzeme. [Interview]. At 10 a.m., November 29, 2018,.

[16] Latgale Region Tourism Association Ezerzeme, Tourism marketing plan, 2018. 